\title{
Therapeutic Drug Monitoring of Imatinib for Chronic Myeloid Leukemia Patients in the Chronic Phase
}

\author{
Naoto Takahashi ${ }^{a}$ Masatomo Miurab \\ a Department of Hematology, Nephrology and Rheumatology, Akita University Graduate School of Medicine, and \\ ${ }^{b}$ Department of Pharmacy, Akita University Hospital, Akita, Japan
}

\section{Key Words}

Imatinib · Therapeutic drug monitoring • Breast cancer resistance protein

\begin{abstract}
Imatinib is approved as a first-line treatment for Philadelphia chromosome-positive chronic myeloid leukemia (CML). Because of the variability in imatinib exposure among patients, therapeutic drug monitoring to maintain a plasma threshold level of about $1,000 \mathrm{ng} / \mathrm{ml}$ would be beneficial during imatinib therapy. Imatinib pharmacokinetics are influenced by body weight, comedication and pharmacogenetic factors, and the drug is excreted into the bile by the breast cancer resistance protein ( $A B C G 2$ gene). To attain the plasma threshold of approximately $1,000 \mathrm{ng} / \mathrm{ml}$, the daily dose for patients with the $A B C G 2421 C / C$ genotype should be $400 \mathrm{mg}$; for patients with the $421 \mathrm{C} / \mathrm{A}$ or $421 \mathrm{~A} / \mathrm{A}$ genotype, the dose should be $300 \mathrm{mg}$. Knowledge of the $A B C G 2421$ genotype could be useful when making dosing decisions aimed at achieving the optimal imatinib exposure. A therapeutic drug monitoring service should be routinely provided to $C M L$ patients taking imatinib. For CML patients who have an imatinib trough level of $1,000 \mathrm{ng} / \mathrm{ml}$ but lack a sufficient clinical response, switching to another tyrosine kinase inhibitor is recommended.

Copyright $\odot 2011$ S. Karger AG, Basel
\end{abstract}

\section{Introduction}

Imatinib mesylate $\left(\right.$ Glivec $^{\circledR}$; Novartis, Basel, Switzerland), an inhibitor of BCR-ABL tyrosine kinase activity, has become the standard treatment for Philadelphia chromosome-positive chronic myeloid leukemia (CML), due to its demonstrated clinical efficacy and ability to produce a durable response and prolonged survival $[1,2]$. However, despite its outstanding efficacy, nearly $20 \%$ of patients who take imatinib do not achieve a complete cytogenetic response (CCyR), which is the major objective of therapy and is associated with prolonged survival [3, 4]; moreover, some patients develop intolerable side effects or drug resistance over time [5]. A major molecular response (MMR) is also considered an important therapeutic target [5]. The probability of loss of CCyR within 7 years is only 3\% among patients with an MMR at 18 months versus $26 \%$ among patients with CCyR but no MMR [6].

Factors that may be associated with a suboptimal response to imatinib and treatment failure include: (i) biological factors, such as the baseline presence or later emergence of a BCR-ABL mutation or other genetic variant $[7,8]$, or mutation of a drug influx transporter involved in the intracellular uptake of the drug $[9,10]$; (ii) clinical features, such as the disease status of the patient

\section{KARGER}

Fax +41613061234 E-Mail karger@karger.ch www.karger.com
(C) 2011 S. Karger AG, Basel

0031-7012/11/0876-0241\$38.00/0

Accessible online at:

www.karger.com/pha
Masatomo Miura, $\mathrm{PhD}$

Department of Pharmacy, Akita University Hospital

1-1-1 Hondo

Akita 010-8543 (Japan)

Tel. +81 18884 6310, E-Mail m-miura@ hos.akita-u.ac.jp 


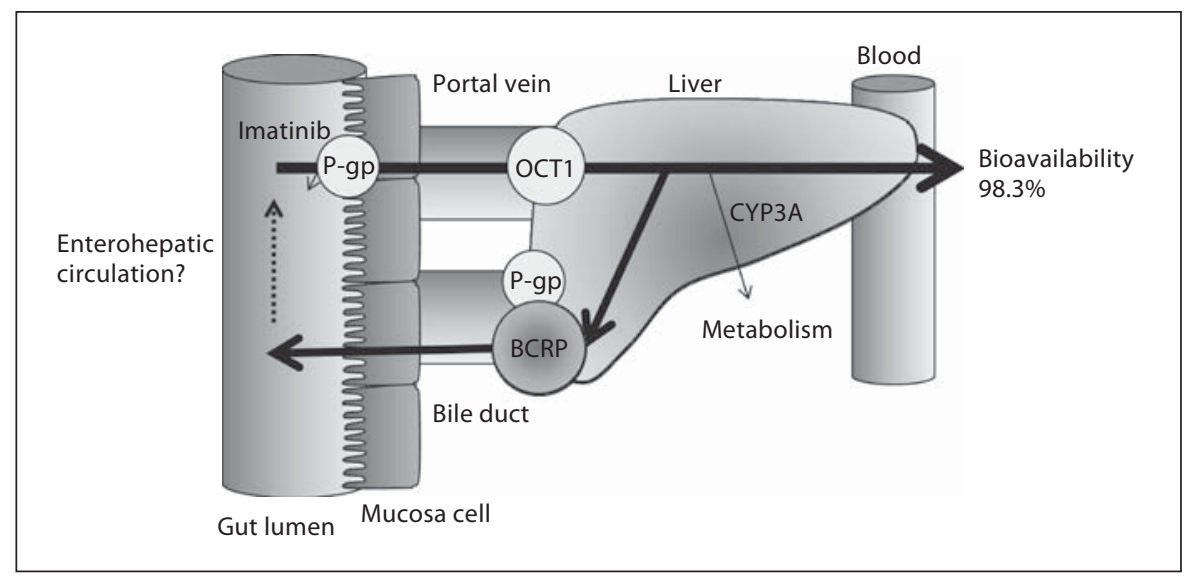

Fig. 1. Schematic representation of the transport and metabolism of imatinib. After oral administration, imatinib is absorbed and interacts slightly with P-glycoprotein (P-gp) at the membrane of intestinal epithelial cells and is then transported to the intestinal lumen. Upon reaching the liver, imatinib is transported into hepatocytes by organic cation transporter 1 (OCT1), where it may undergo metabolism to $\mathrm{N}$-desmethylimatinib by hepatic cytochrome P450 (CYP) 3A4. A portion of the imatinib and N-des- methylimatinib is then glucuronidated to $\mathrm{O}$ - or $\mathrm{N}$-glucuronides by UDP-glucuronosyltransferases. Transport out of the hepatocytes into the bile occurs via breast cancer resistance protein (BCRP), which is located at the hepatocyte apical membrane. Imatinib and $\mathrm{N}$-desmethylimatinib glucuronides are excreted into the bile and may undergo enterohepatic recirculation and reconversion to imatinib and $\mathrm{N}$-desmethylimatinib by colonic bacterial glucuronidases. The oral bioavailability of imatinib is $98.3 \%$. or the Sokal risk score at baseline [11], and (iii) pharmacokinetic factors, such as drug metabolism or transport, drug-drug interactions [12, 13] and adherence [14]. In this article, we review the factors affecting imatinib exposure, in particular drug transporter polymorphisms, as well as the clinical significance of therapeutic drug monitoring of imatinib.

\section{Pharmacokinetics}

After oral administration, imatinib is rapidly and completely absorbed with an oral bioavailability of $98.3 \%$ [15], after which it is extensively metabolized, and up to $80 \%$ of the administered dose is recovered in the feces as metabolites or unchanged drug [16] (fig. 1). The mean plasma half-life of imatinib is $13.5-18.2 \mathrm{~h}$ [15-18]. Imatinib and its metabolites are excreted predominantly via the biliary-fecal route [16] by the ATP-binding cassette $(\mathrm{ABC})$ transporters, breast cancer resistance protein (BCRP) and P-glycoprotein. The main metabolite of imatinib, the N-desmethylderivative CGP74588 (N-desmethylimatinib), is formed in the liver by cytochrome $\mathrm{P} 450$ (CYP) 3A4, while a number of other enzymes, including CYP1A2, CYP2D6, CYP2C9 and CYP2C19, are involved in the formation of minor metabolites $[19,20]$. CGP74588 accounts for approximately $20 \%$ of the plasma drug level in patients and has similar biological activity to the parent compound but a longer terminal half-life (85-95 h), as measured after discontinuation of therapy [17]. Indeed, Gréen et al. [21] reported that the effect and potency of CGP74588 might have clinical importance.

Imatinib and CGP74588 are mainly glucuronidated to inactive $\mathrm{O}$ - and $\mathrm{N}$-glucuronides [16] by UDP-glucuronosyltransferases; however, the UDP-glucuronosyltransferase isoforms involved in the glucuronidation of imatinib have not yet been determined. These glucuronides are excreted into the bile, where they may be converted back to the parent drug and CGP74588 by bacterial $\beta$-glucuronidases in the gut lumen. They are then reabsorbed through the process of enterohepatic recirculation, which is evidenced by a secondary plasma peak in the concentrationtime profile of imatinib and by the observation that there are conjugates present in the plasma and urine that are not detected in the feces [16]. However, the extent of the biliary excretion of imatinib glucuronic acid conjugates and their metabolites has not yet been reported.

Urinary excretion accounts for 3-5\% of the daily imatinib dose [22]. Although organic anion transporters and organic cation transporter (OCT) 2 play an essential role in the renal elimination of imatinib, an in vitro study showed that organic anion transporters 1 and 3 and OCT2 do not transport imatinib, which is consistent with its relatively low renal clearance [23]. 
Table 1. Correlation of imatinib pharmacokinetics with clinical response

\begin{tabular}{lllll}
\hline Ref. & $\begin{array}{l}\text { Patients } \\
\mathrm{n}\end{array}$ & $\begin{array}{l}\text { Imatinib } \\
\text { dose } \\
\text { mg/day }\end{array}$ & $\begin{array}{l}\text { Imatinib } \mathrm{C}_{0} \\
\mathrm{ng} / \mathrm{ml}\end{array}$ & $\begin{array}{l}\text { Correlation } \\
\text { with response }\end{array}$ \\
\hline $\begin{array}{l}\text { Marin } \\
\text { et al. [14] }\end{array}$ & 84 & 400 & $\begin{array}{l}900 \\
(400-1,600)\end{array}$ & yes (MMR) \\
\hline $\begin{array}{l}\text { Picard } \\
\text { et al. [25] }\end{array}$ & 50 & 400 & $1,058 \pm 557$ & yes (CCyR, \\
\hline $\begin{array}{l}\text { Larson } \\
\text { et al. [26] }\end{array}$ & 351 & 400 & $979 \pm 530$ & yes (CCyR) \\
\hline $\begin{array}{l}\text { Forrest } \\
\text { et al. [27] }\end{array}$ & 78 & 400 & 999 & no (CCyR, \\
\hline $\begin{array}{l}\text { Widmer } \\
\text { et al. [28] }\end{array}$ & 20 & 400 & NA & $\begin{array}{l}\text { no (AUCu vs. } \\
\text { HR) }\end{array}$ \\
\hline $\begin{array}{l}\text { Singh } \\
\text { et al. [29] }\end{array}$ & 40 & 400 & 700 vs. & $\begin{array}{l}\text { yes (clinical } \\
\text { response) }\end{array}$ \\
\hline $\begin{array}{l}\text { Takahashi } \\
\text { et al. [30] }\end{array}$ & 254 & 400 & $1,011 \pm 565$ & yes (MMR) \\
\hline
\end{tabular}

$\mathrm{NA}=$ Not available; $\mathrm{AUCu}=$ free area under the curve; $\mathrm{HR}=$ hematological response.

Both imatinib and CGP74588 are transferred to human breast milk [24]. The milk-plasma imatinib ratio after a daily oral administration of a 400-mg dose reaches 0.5 for imatinib and 0.9 for CGP74588. From an average milk intake for an infant of 728-777 $\mathrm{ml} /$ day (range $450-$ $1,165 \mathrm{ml} /$ day), the amount of drug transferred to an infant can be calculated to be less than $3 \mathrm{mg} /$ day [24].

\section{The Need for Therapeutic Drug Monitoring}

It was recently reported that variation in the imatinib plasma trough concentration $\left(\mathrm{C}_{0}\right)$ can affect the clinical response of patients (table 1) [14, 25-30]. Picard et al. [25] reported that a steady-state imatinib $\mathrm{C}_{0}$ measured after at least 12 months of treatment with a standard imatinib dose correlated with both the cytogenetic and molecular responses. Those investigators suggested that the threshold for the imatinib $\mathrm{C}_{0}$ should be set above $1,002 \mathrm{ng} / \mathrm{ml}$, as a concentration-effect receiver operating characteristic curve analysis indicated that this level was significantly associated with a MMR with greatest sensitivity (77\%) and specificity (71\%) [25]. In addition, Larson et al. [26] reported that a steady-state imatinib $\mathrm{C}_{0}$ at or above 1,000 $\mathrm{ng} / \mathrm{ml}$ on day 28 was predictive of a CCyR, while Takahashi et al. [30] found that the MMR was significantly associated with the age of the patients and the imatinib $\mathrm{C}_{0}$, whereas the CCyR was associated only with the daily dosage. Both Takahashi et al. [30] and Marin et al. [14] reported that patients with an imatinib $\mathrm{C}_{0}$ of less than $1,002 \mathrm{ng} / \mathrm{ml}$ have a significantly lower rate of successfully achieving an improved MMR ( $\mathrm{p}=0.012$ and 0.02 , respectively), but not CCyR. Thus, the efficacy of the threshold $\mathrm{C}_{0}$ of imatinib should be set above $1,002 \mathrm{ng} / \mathrm{ml}$ for CML patients.

Patients are more likely to obtain a satisfactory response if an adequate imatinib $\mathrm{C}_{0}$ is achieved and maintained. Although additional monitoring of CGP74588 may also be useful [31], it is not presently considered. Furthermore, the percent deviation of the observed imatinib $\mathrm{C}_{0}$ from the standardized trough level appears to be larger if samples are collected outside the 6-hour window between 21 and $27 \mathrm{~h}$ after dosing [18]. For that reason, sampling should be carried out within $24 \pm 2 \mathrm{~h}$ after taking imatinib. According to the European Leukemia Net recommendations [5], the clinical response of CML patients receiving imatinib therapy should be evaluated at 3, 6, 12 and 18 months. If patients do not achieve CCyR or MMR at these time points, the imatinib $\mathrm{C}_{0}$ should be assayed and BCR-ABL should be analyzed for mutations.

\section{Standard Dose of Imatinib and Trough Levels}

Based on the IRIS study, the established standard dose of imatinib is $400 \mathrm{mg} /$ day for patients with chronic-phase CML $[3,32]$. A phase I dose escalation study of imatinib from 25 to $1,000 \mathrm{mg} /$ day across 14 dose levels was conducted in 83 patients with chronic-phase CML, but a maximum tolerated dose was not identified [33]. Most patients who are administered a dose of $300 \mathrm{mg} /$ day or greater respond to treatment, and $400 \mathrm{mg} / \mathrm{day}$ is recommended as a standard dose, based on clinical and preclinical data $[12,33]$. Several studies have suggested that administration of a dose higher than $400 \mathrm{mg} /$ day may improve the response in some patients [34] and, in fact, a better response was observed in the accelerated and blast phases of CML with a dose of $600 \mathrm{mg} /$ day [35].

At the recommended dose of $400 \mathrm{mg} /$ day, imatinib sometimes causes severe adverse events, such as myelosuppression, edema and skin rash, which in turn may lead to poor compliance, premature cessation of treatment or failure of the therapy. To avoid these unfavorable clinical 
situations, the daily dose of imatinib is often reduced from 400 to $200-300 \mathrm{mg} /$ day in clinical practice [36-40], although maintaining a low dose of imatinib is not generally recommended because of the risk of acquiring BCRABL point mutations. Kawaguchi et al. [40] suggested that a dose of $300 \mathrm{mg} /$ day of imatinib might be sufficient to achieve a CCyR or MMR in some Japanese patients, because the significantly smaller body surface area of these patients enables a lower imatinib dose to provide a sufficient $\mathrm{C}_{0}$ during CML treatment $[39,40]$. The mean steady-state imatinib $\mathrm{C}_{0}$ obtained $24 \mathrm{~h}$ after taking a 400 $\mathrm{mg}$ daily dose ranged from 900 to $1,400 \mathrm{ng} / \mathrm{ml}[14,25-27$, 30]; however, even among those taking the same $400 \mathrm{mg} /$ day dose, the imatinib $C_{0}$ varied widely $(153-3,910 \mathrm{ng} / \mathrm{ml})$ [26]. Kawaguchi et al. [40] reported that the mean $\mathrm{C}_{0}$ obtained with a dose of $300 \mathrm{mg} /$ day was $1,150 \pm 440 \mathrm{ng} / \mathrm{ml}$ $(n=9)$, exceeding the effective plasma threshold for imatinib $\mathrm{C}_{0}(1,002 \mathrm{ng} / \mathrm{ml})$. Similarly, Sakai et al. [39] reported that the median imatinib $\mathrm{C}_{0}$ in patients administered 300 $\mathrm{mg} /$ day was $1,130 \mathrm{ng} / \mathrm{ml}$, though this result was based on a relatively small number of patients $(n=13)$.

\section{Influence of Comedication on Imatinib Pharmacokinetics}

Imatinib absorption is not influenced by food [41]. The concomitant administration of an $\mathrm{Mg}^{2+}-\mathrm{Al}^{3+}$-based antacid is not associated with meaningful alterations in imatinib absorption either [41]. Likewise, administration of $40 \mathrm{mg}$ of omeprazole, a proton pump inhibitor, is not associated with a change in the pharmacokinetics of imatinib after a 400-mg dose [42]. Although proton pump inhibitors can influence the absorption and metabolism of drugs by interacting with P-glycoprotein and the CYP enzyme system, no drug interactions between proton pump inhibitors and imatinib via CYP or P-glycoprotein have been observed.

A drug interaction does occur with coadministration of imatinib and rifampicin or St. John's wort, two CYP3A inducers, resulting in a decrease in the plasma concentration of imatinib [43, 44]. In one study, rifampicin significantly reduced the maximum plasma imatinib concentration $\left(\mathrm{C}_{\max }\right)$ by $54 \%$ and reduced the dose-adjusted area under the time-concentration curve extending from 0 to $24 \mathrm{~h}\left(\mathrm{AUC}_{0-24}\right)$ by $68 \%$. It also increased the $\mathrm{C}_{\max }$ and AUC $_{0-24}$ for CGP74588 by 88.6 and $23.9 \%$, respectively [43]. In addition, Smith et al. [44] reported that St. John's wort significantly reduced the $\mathrm{C}_{\max }$ and $\mathrm{AUC}_{0-\infty}$ for imatinib by 29 and $32 \%$, respectively. Similarly, Frye et al. [45] reported that coadministration of imatinib with St. John's wort significantly reduced the $\mathrm{C}_{\max }$ and $\mathrm{AUC}_{0-\infty}$ of imatinib by 18 and 30\%, respectively. Conversely, ketoconazole, a potent CYP3A4 inhibitor, significantly increased the $\mathrm{C}_{\max }$ and $\mathrm{AUC}_{0-24}$ for imatinib by 26 and $40 \%$, respectively, and decreased the $\mathrm{C}_{\max }$ and $\mathrm{AUC}_{0-24}$ for CGP74588e by 22.6 and $13 \%$, respectively [46]. These findings indicate that CGP74588 is produced by CYP3A4 in the small intestine and liver and suggest that, although the clinical effect of St. John's wort or ketoconazole on the response to imatinib appears to be small, one should be alert for this combination. Notably, coadministration of the CYP3A4 inhibitor ritonavir with imatinib for 3 days reportedly produced no apparent drug-drug interaction in patients in the steady state [13]. However, the period examined in that study was too short to draw a meaningful conclusion about a drug-drug interaction between imatinib and ritonavir. Imatinib is also metabolized to a minor extent by CYP1A2; nonetheless, the pharmacokinetics of imatinib are not affected by tobacco smoking, which is known to induce CYP1A1 and CYP1A2 [47, 48].

In the absence of prospective data supporting the maintenance of imatinib $\mathrm{C}_{0}$ at or above $1,000 \mathrm{ng} / \mathrm{ml}$, escalation of the imatinib dose should be the first choice for a change in therapy for patients with no drug-drug interaction or adherence issues. For CML patients that have an imatinib $\mathrm{C}_{0}$ of $1,000 \mathrm{ng} / \mathrm{ml}$ but lack a sufficient clinical response, switching to another tyrosine kinase inhibitor is recommended.

\section{Factors Influencing Imatinib Exposure}

\section{Effect of Liver and Renal Dysfunction}

Ramanathan et al. [49] reported that imatinib exposure does not differ between patients with normal liver function and those showing liver dysfunction. Although imatinib is metabolized by hepatic CYP enzymes, their study showed no correlation between imatinib exposure and liver function or the occurrence of dose-limiting toxicities. On the other hand, the hemoglobin concentration was correlated with the clearance of oral imatinib [50].

Pappas et al. [51] reported that the pharmacokinetic parameters for imatinib in a patient on hemodialysis did not differ from those in patients with normal renal function. On the other hand, Gibbons et al. [22] reported that the dose-adjusted $\mathrm{C}_{\max }$ for imatinib was approximately 2.2-fold higher and the imatinib $\mathrm{AUC}_{0-24}$ was significantly greater in patients with mild or moderate renal dysfunction than in those with normal renal function. It 
has also been reported that the steady-state imatinib $\mathrm{C}_{0}$ is significantly associated with creatinine clearance in patients with gastrointestinal stromal tumors [52].

\section{Body Weight}

A population pharmacokinetic analysis by Schmidli et al. [50] $(\mathrm{n}=371)$ found that body weight was correlated with the clearance of oral imatinib. Kawaguchi et al. [40] reported that in patients $(n=9)$ with a smaller body size, a dose of $300 \mathrm{mg} /$ day is sufficient to obtain therapeutic efficacy equivalent to the standard $400 \mathrm{mg}$ /day dose, as the imatinib $\mathrm{C}_{0}$ exceeds the therapeutic concentration $(1,002 \mathrm{ng} / \mathrm{ml})$. For example, a lower dose of imatinib (200-300 $\mathrm{mg} /$ day) provided clinical benefit to 5 Japanese CML patients with a low body surface area (BSA; median value, $1.46 \mathrm{~m}^{2}$ ) [36], and Korean CML patients with a low BSA (median value, $1.55 \mathrm{~m}^{2}$ ) benefited similarly from 300 $\mathrm{mg} /$ day imatinib [37]. An IRIS subanalysis identified a weak correlation between steady-state imatinib $\mathrm{C}_{0}$ and both body weight $\left(\mathrm{r}^{2}=0.015\right)$ and BSA $\left(\mathrm{r}^{2}=0.038 ; \mathrm{n}=315\right)$ [26]. On the other hand, no correlation was observed between imatinib $\mathrm{C}_{0}$ and body weight or BSA in 254 Japanese CML patients [30]. Indeed, given the large interpatient variability in imatinib $\mathrm{C}_{0}(54 \%)$, the effects of age, sex and body weight and BSA on imatinib exposure are unlikely to be clinically significant [26].

\section{The Impact of Pharmacogenetic Variation on Imatinib Pharmacokinetics}

Pharmacogenetic research on imatinib has focused in part on the relation between imatinib exposure and the clinical response to imatinib (pharmacodynamic effect) and the expression levels of enzymes such as CYP3A4/5 and transporters such as P-glycoprotein, BCRP and OCT1 (pharmacokinetic effects, fig. 1). For example, the level of SLC22A1 (OCT1) expression likely correlates with the intracellular imatinib concentration, as primary CML cells expressing high levels of OCT1 show greater drug uptake than those exhibiting more modest OCT1 expression [10, 53, 54].

Imatinib exposure may also be influenced by various polymorphisms [55]. In adults, the main CYP3A isoforms are CYP3A4 and CYP3A5, which show approximately $83 \%$ amino acid sequence identity $[56,57]$. Two polymorphisms, CYP $3 A 4^{*} 1 B(-392 \mathrm{~A} \rightarrow \mathrm{G})$ and $C Y P 3 A 5^{*} 3$ $(6986 \mathrm{~A} \rightarrow \mathrm{G})$, have no significant effect on the plasma concentration of imatinib [58-60], suggesting that CYP3A4 and CYP3A5 polymorphisms likely do not have a clini-

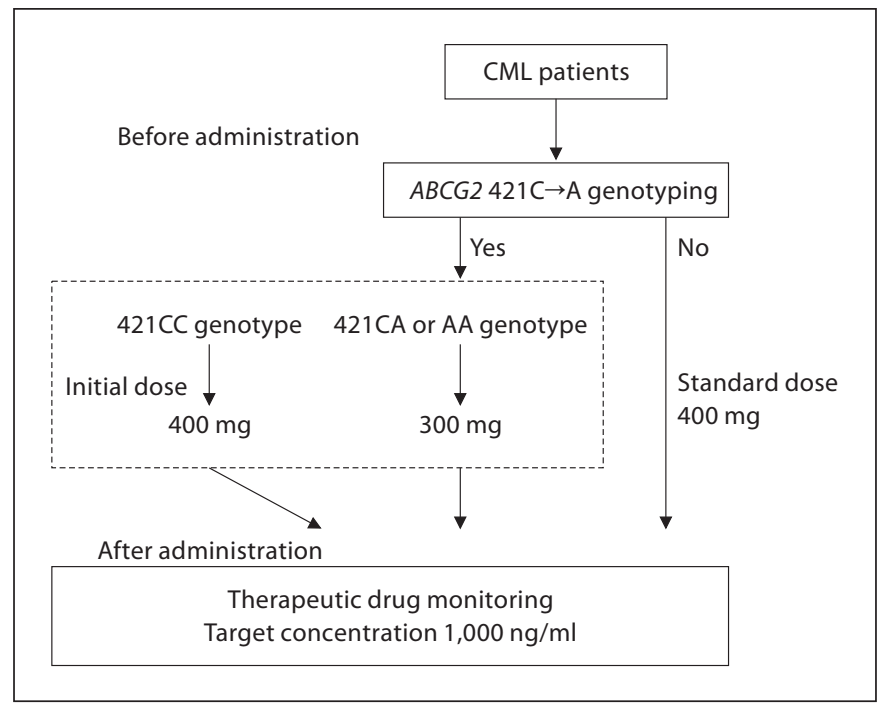

Fig. 2. A proposal for a therapeutic strategy for CML patients, based on $A B C G 2$ polymorphism analysis. If analysis for the $A B C G 2421 C \rightarrow$ A genetic polymorphism is possible in the hospital laboratory, the imatinib dosage should be decided on the basis of genotype. To achieve the $1,000 \mathrm{ng} / \mathrm{ml} \mathrm{C}_{0}$ in plasma, the initial daily dosage of imatinib should be $400 \mathrm{mg}$ for patients with the ABCG2 421C/C genotype and $300 \mathrm{mg}$ for patients with the $421 \mathrm{C} / \mathrm{A}$ or $421 \mathrm{~A} / \mathrm{A}$ genotype.

cally significant effect on imatinib exposure. On the other hand, imatinib is a substrate for the $\mathrm{ABC}$ efflux transporters $\mathrm{ABCB} 1$ and ABCG2 [61-65]. P-glycoprotein, which is encoded by the $A B C B 1$ gene, is a membrane efflux transporter normally expressed in the small intestine and biliary canalicular front of hepatocytes [66]. Three studies have focused on whether $A B C B 1$ polymorphisms, including $1236 \mathrm{C} \rightarrow \mathrm{T}, 2677 \mathrm{G} \rightarrow \mathrm{T} / \mathrm{A}$ and $3435 \mathrm{C} \rightarrow \mathrm{T}$, affect imatinib pharmacokinetics [58-60]. Gurney et al. [59] $($ sample size $=22)$ reported that clearance of oral imatinib in patients receiving $600 \mathrm{mg}$ daily was significantly lower in subjects with the $A B C B 11236 \mathrm{C} / \mathrm{C}, 2677 \mathrm{G} / \mathrm{G}$ and $3435 \mathrm{C} / \mathrm{C}$ genotypes than in those with the corresponding $A B C B 1$ 1236T/T, 2677T/T and 3435T/T genotypes [59]. However, Gardner et al. [58] (sample size $=82$ ) reported that the $A B C B 13435 \mathrm{C} \rightarrow$ T polymorphism had no significant effect on clearance of oral imatinib, and Takahashi et al. [60] (sample size $=62$ ) reported that the $1236 \mathrm{C} \rightarrow \mathrm{T}$, $2677 \mathrm{G} \rightarrow \mathrm{T} / \mathrm{A}$ and $3435 \mathrm{C} \rightarrow \mathrm{T}$ polymorphisms had no significant effect on dose-adjusted imatinib $\mathrm{C}_{0}$.

BCRP is encoded by the $A B C G 2$ gene and is widely expressed in the small intestine, liver and placenta $[67,68]$. Takahashi et al. [60] (sample size $=62$ ) reported that the dose-adjusted imatinib $C_{0}$ was significantly lower in Japa- 
nese patients with the $A B C G 2421 \mathrm{C} / \mathrm{C}$ genotype than in patients with the $\mathrm{C} / \mathrm{A}+\mathrm{A} / \mathrm{A}$ genotypes. In addition, $\mathrm{Pe}-$ tain et al. [69] (sample size $=46)$ reported that imatinib clearance in patients carrying the ABCG2 421C/A genotype was significantly lower than in those with the $421 \mathrm{C} / \mathrm{C}$ genotype. It thus appears that among CML patients, the $A B C G 2421 \mathrm{C} / \mathrm{A}$ or $\mathrm{A} / \mathrm{A}$ genotype is associated with a higher imatinib exposure $\left(\right.$ as $\mathrm{C}_{0}$ ) than the $421 \mathrm{C} / \mathrm{C}$ genotype.

On the other hand, imatinib is also a substrate of the uptake transporter OCT1 $[53,54,70]$, which is encoded by SLC22A1. OCT1 is primarily expressed on hepatocytes, suggesting that it plays a role in substrate uptake into the liver [71-73]. However, no association between the clearance of oral imatinib and the SLC22A1 286C $\rightarrow \mathrm{T}$ or $1498 \mathrm{G} \rightarrow$ A polymorphisms has been observed [23], and Takahashi et al. [60] (sample size $=62$ ) reported that the SLC22A1156T $\rightarrow$ C, $480 \mathrm{G} \rightarrow \mathrm{C}, 1022 \mathrm{C} \rightarrow \mathrm{T}$ and $1222 \mathrm{~A} \rightarrow \mathrm{G}$ polymorphisms have no significant effect on dose-adjusted imatinib $\mathrm{C}_{0}$. Apparently, the $S L C 22 \mathrm{~A} 1$ polymorphisms analyzed to date have no important effect on imatinib exposure. It may be that although OCT contributes to the cellular uptake of imatinib, it does not contribute to imatinib exposure.

The involvement of multiple human transporters in imatinib pharmacokinetics makes the investigation of imatinib transport mechanisms difficult. However, among the various drug transporters, BCRP appears to most strongly influence imatinib exposure (fig. 1). Takahashi et al. [60] reported that to attain the $1,000 \mathrm{ng} / \mathrm{ml}$ drug plasma threshold, the daily dosage of imatinib should be $400 \mathrm{mg}$ in patients with the ABCG2 421C/C genotype and $300 \mathrm{mg}$ in those with the $421 \mathrm{C} / \mathrm{A}$ or 421A/A genotype. Knowledge of the patient's ABCG2 $421 \mathrm{C} \rightarrow \mathrm{A}$ genotype before initiating therapy could be useful when making dosing decisions aimed at achieving optimal imatinib exposure, and in conjunction with therapeutic drug monitoring could aid patient management (fig. 2).

\section{Conclusions}

The interindividual variation of imatinib $\mathrm{C}_{0}$ is influenced by multiple factors, including genetic polymorphisms, environmental factors, concomitant disease and coadministered drugs. Therefore, a therapeutic drug monitoring service should be routinely provided to CML patients taking imatinib. For CML patients who have an imatinib $C_{0}$ of $1,000 \mathrm{ng} / \mathrm{ml}$ but lack a sufficient clinical response, switching to another tyrosine kinase inhibitor is recommended. In addition, knowledge of the ABCG2 $421 \mathrm{C} \rightarrow$ A genotype before initiating therapy could be useful when making dosing decisions aimed at achieving optimal imatinib exposure.

\section{References}

1 Goldman JM: How I treat chronic myeloid leukemia in the imatinib era. Blood 2007; 110:2828-2837.

$\checkmark 2$ O'Brien SG, Guilhot F, Larson RA, Gathmann I, Baccarani M, Cervantes F, Cornelissen JJ, Fischer T, Hochhaus A, Hughes T, Lechner K, Nielsen JL, Rousselot P, Reiffers J, Saglio G, Shepherd J, Simonsson B, Gratwohl A, Goldman JM, Kantarjian H, Taylor K, Verhoef G, Bolton AE, Capdeville R, Druker BJ: Imatinib compared with interferon and low-dose cytarabine for newly diagnosed chronic-phase chronic myeloid leukemia. N Engl J Med 2003;348:994-1004.

$\checkmark 3$ Druker BJ, Guilhot F, O’Brien SG, Gathmann I, Kantarjian H, Gattermann N, Deininger MW, Silver RT, Goldman JM, Stone RM, Cervantes F, Hochhaus A, Powell BL, Gabrilove JL, Rousselot P, Reiffers J, Cornelissen JJ, Hughes T, Agis H, Fischer T, Verhoef G, Shepherd J, Saglio G, Gratwohl A, Nielsen JL, Radich JP, Simonsson B, Taylor K, Baccarani M, So C, Letvak L, Larson RA: Five-year follow-up of patients receiving imatinib for chronic myeloid leukemia. N Engl J Med 2006;355:2408-2417.
-4 De Lavallade H, Apperley JF, Khorashad JS, Milojkovic D, Reid AG, Bua M, Szydlo R, Olavarria E, Kaeda J, Goldman JM, Marin D: Imatinib for newly diagnosed patients with chronic myeloid leukemia: incidence of sustained responses in an intention-to-treat analysis. J Clin Oncol 2008;26:3358-3363.

5 Baccarani M, Cortes J, Pane F, Niederwieser D, Saglio G, Apperley J, Cervantes F, Deininger M, Gratwohl A, Guilhot F, Hochhaus A, Horowitz M, Hughes T, Kantarjian H, Larson R, Radich J, Simonsson B, Silver RT, Goldman J, Hehlmann R: Chronic myeloid leukemia: an update of concepts and management recommendations of European Leukemia Net. J Clin Oncol 2009;27:6041-6051.

-6 Hughes TP, Hochhaus A, Branford S, Muller MC, Kaeda JS, Foroni L, Druker BJ, Guilhot F, Larson RA, O'Brien SG, Rudoltz MS, Mone M, Wehrle E, Modur V, Goldman JM, Radich JP: Long-term prognostic significance of early molecular response to imatinib in newly diagnosed chronic myeloid leukemia: an analysis from the International Randomized Study of Interferon and STI571 (IRIS). Blood 2010;116:3758-3765.
7 Gorre ME, Mohammed M, Ellwood K, Hsu N, Paquette R, Rao PN, Sawyers CL: Clinical resistance to STI-571 cancer therapy caused by $B C R-A B L$ gene mutation or amplification. Science 2001;293:876-880.

$\checkmark 8$ Radich JP, Dai H, Mao M, Oehler V, Schelter J, Druker B, Sawyers C, Shah N, Stock W, Willman CL, Friend S, Linsley PS: Gene expression changes associated with progression and response in chronic myeloid leukemia. Proc Natl Acad Sci USA 2006;103:27942799.

-9 White DL, Dang P, Engler J, Frede A, Zrim S, Osborn M, Saunders VA, Manley PW, Hughes TP: Functional activity of the OCT-1 protein is predictive of long-term outcome in patients with chronic-phase chronic myeloid leukemia treated with imatinib. J Clin Oncol 2010;28:2761-2767.

10 Thomas J, Wang L, Clark RE, Pirmohamed $\mathrm{M}$ : Active transport of imatinib into and out of cells: implications for drug resistance. Blood 2004; 104:3739-3745.

$>11$ Crossman LC, O’Brien SG: Imatinib therapy in chronic myeloid leukemia. Hematol Oncol Clin North Am 2004;18:605-617, viii. 
12 Peng B, Hayes M, Resta D, Racine-Poon A, Druker BJ, Talpaz M, Sawyers CL, Rosamilia M, Ford J, Lloyd P, Capdeville R: Pharmacokinetics and pharmacodynamics of imatinib in a phase I trial with chronic myeloid leukemia patients. J Clin Oncol 2004;22:935-942.

13 Cortes JE, Egorin MJ, Guilhot F, Molimard M, Mahon FX: Pharmacokinetic/pharmacodynamic correlation and blood-level testing in imatinib therapy for chronic myeloid leukemia. Leukemia 2009;23:1537-1544.

14 Marin D, Bazeos A, Mahon FX, Eliasson L, Milojkovic D, Bua M, Apperley JF, Szydlo R, Desai R, Kozlowski K, Paliompeis C, Latham V, Foroni L, Molimard M, Reid A, Rezvani K, de Lavallade H, Guallar C, Goldman J, Khorashad JS: Adherence is the critical factor for achieving molecular responses in patients with chronic myeloid leukemia who achieve complete cytogenetic responses on imatinib. J Clin Oncol 2010;28:2381-2388.

15 Peng B, Dutreix C, Mehring G, Hayes MJ, Ben-Am M, Seiberling M, Pokorny R, Capdeville R, Lloyd P: Absolute bioavailability of imatinib (Glivec) orally versus intravenous infusion. J Clin Pharmacol 2004;44:158-162.

16 Gschwind HP, Pfaar U, Waldmeier F, Zollinger M, Sayer C, Zbinden P, Hayes M, Pokorny R, Seiberling M, Ben-Am M, Peng B, Gross G: Metabolism and disposition of imatinib mesylate in healthy volunteers. Drug Metab Dispos 2005;33:1503-1512.

17 Le Coutre P, Kreuzer KA, Pursche S, Bonin M, Leopold T, Baskaynak G, Dorken B, Ehninger G, Ottmann O, Jenke A, Bornhauser M, Schleyer E: Pharmacokinetics and cellular uptake of imatinib and its main metabolite CGP74588. Cancer Chemother Pharmacol 2004:53:313-323.

18 Wang Y, Chia YL, Nedelman J, Schran H, Mahon FX, Molimard M: A therapeutic drug monitoring algorithm for refining the imatinib trough level obtained at different sampling times. Ther Drug Monit 2009;31:579584.

19 O'Brien SG, Meinhardt P, Bond E, Beck J, Peng B, Dutreix C, Mehring G, Milosavljev S, Huber C, Capdeville R, Fischer T: Effects of imatinib mesylate (STI571, Glivec) on the pharmacokinetics of simvastatin, a cytochrome p450 3A4 substrate, in patients with chronic myeloid leukaemia. Br J Cancer 2003;89:1855-1859.

20 Van Erp NP, Gelderblom H, Karlsson MO, Li J, Zhao M, Ouwerkerk J, Nortier JW, Guchelaar HJ, Baker SD, Sparreboom A: Influence of CYP3A4 inhibition on the steady-state pharmacokinetics of imatinib. Clin Cancer Res 2007;13:7394-7400.

21 Green H, Skoglund K, Rommel F, Mirghani RA, Lotfi K: CYYP3A activity influences imatinib response in patients with chronic myeloid leukemia: a pilot study on in vivo CYP3A activity. Eur J Clin Pharmacol 2010; 66:383-386.

22 Gibbons J, Egorin MJ, Ramanathan RK, Fu $\mathrm{P}$, Mulkerin DL, Shibata S, Takimoto $\mathrm{CH}$, Mani S, Lo Russo PA, Grem JL, Pavlick A, Lenz HJ, Flick SM, Reynolds S, Lagattuta TF,
Parise RA, Wang Y, Murgo AJ, Ivy SP, Remick SC: Phase I and pharmacokinetic study of imatinib mesylate in patients with advanced malignancies and varying degrees of renal dysfunction: a study by the National Cancer Institute organ dysfunction working group. J Clin Oncol 2008;26:570-576.

23 Hu S, Franke RM, Filipski KK, Hu C, Orwick SJ, de Bruijn EA, Burger H, Baker SD, Sparreboom A: Interaction of imatinib with human organic ion carriers. Clin Cancer Res 2008;14:3141-3148.

24 Gambacorti-Passerini CB, Tornaghi L, Marangon E, Franceschino A, Pogliani EM, D'Incalci M, Zucchetti M: Imatinib concentrations in human milk. Blood 2007;109:1790.

25 Picard S, Titier K, Etienne G, Teilhet E, Ducint $\mathrm{D}$, Bernard MA, Lassalle R, Marit G, Reiffers J, Begaud B, Moore N, Molimard M, Mahon FX: Trough imatinib plasma levels are associated with both cytogenetic and molecular responses to standard-dose imatinib in chronic myeloid leukemia. Blood 2007;109:3496-3499.

26 Larson RA, Druker BJ, Guilhot F, O’Brien SG, Riviere GJ, Krahnke T, Gathmann I, Wang Y: Imatinib pharmacokinetics and its correlation with response and safety in chronic-phase chronic myeloid leukemia: a subanalysis of the iris study. Blood 2008;111:4022-4028.

27 Forrest DL, Trainor S, Brinkman RR, Barnett MJ, Hogge DE, Nevill TJ, Shepherd JD, Nantel SH, Toze CL, Sutherland HJ, Song KW, Lavoie JC, Power MM, Abou-Mourad Y, Smith CA: Cytogenetic and molecular responses to standard-dose imatinib in chronic myeloid leukemia are correlated with Sokal risk scores and duration of therapy but not trough imatinib plasma levels. Leuk Res 2009;33:271-275.

28 Widmer N, Decosterd LA, Leyvraz S, Duchosal MA, Rosselet A, Debiec-Rychter M, Csajka C, Biollaz J, Buclin T: Relationship of imatinib-free plasma levels and target genotype with efficacy and tolerability. Br J Cancer 2008;98:1633-1640.

29 Singh N, Kumar L, Meena R, Velpandian T: Drug monitoring of imatinib levels in patients undergoing therapy for chronic myeloid leukaemia: comparing plasma levels of responders and non-responders. Eur J Clin Pharmacol 2009;65:545-549.

30 Takahashi N, Wakita H, Miura M, Scott SA, Nishii K, Masuko M, Sakai M, Maeda Y, Ishige K, Kashimura M, Fujikawa K, Fukazawa M, Katayama T, Monma F, Narita M, Urase F, Furukawa T, Miyazaki Y, Katayama N, Sawada K: Correlation between imatinib pharmacokinetics and clinical response in Japanese patients with chronic-phase chronic myeloid leukemia. Clin Pharmacol Ther 2010;88:809-813.

31 Delbaldo C, Chatelut E, Re M, Deroussent A, Seronie-Vivien S, Jambu A, Berthaud P, Le Cesne A, Blay JY, Vassal G: Pharmacokinetic-pharmacodynamic relationships of imatinib and its main metabolite in patients with advanced gastrointestinal stromal tumors. Clin Cancer Res 2006;12:6073-6078.
32 Hochhaus A, O’Brien SG, Guilhot F, Druker BJ, Branford S, Foroni L, Goldman JM, Muller MC, Radich JP, Rudoltz M, Mone M, Gathmann I, Hughes TP, Larson RA: Sixyear follow-up of patients receiving imatinib for the first-line treatment of chronic myeloid leukemia. Leukemia 2009;23:10541061 .

33 Druker BJ, Talpaz M, Resta DJ, Peng B, Buchdunger E, Ford JM, Lydon NB, Kantarjian H, Capdeville R, Ohno-Jones S, Sawyers CL: Efficacy and safety of a specific inhibitor of the BCR-ABL tyrosine kinase in chronic myeloid leukemia. N Engl J Med 2001;344: 1031-1037.

34 Cortes JE, Kantarjian HM, Goldberg SL, Powell BL, Giles FJ, Wetzler M, Akard L, Burke JM, Kerr R, Saleh M, Salvado A, McDougall K, Albitar M, Radich J: High-dose imatinib in newly diagnosed chronic-phase chronic myeloid leukemia: high rates of rapid cytogenetic and molecular responses. J Clin Oncol 2009;27:4754-4759.

35 Talpaz M, Silver RT, Druker BJ, Goldman JM, Gambacorti-Passerini C, Guilhot F, Schiffer CA, Fischer T, Deininger MW, Lennard AL, Hochhaus A, Ottmann OG, Gratwohl A, Baccarani M, Stone R, Tura S, Mahon FX, Fernandes-Reese S, Gathmann I, Capdeville R, Kantarjian HM, Sawyers CL: Imatinib induces durable hematologic and cytogenetic responses in patients with accelerated phase chronic myeloid leukemia: results of a phase 2 study. Blood 2002;99:1928-1937.

36 Horikoshi A, Takei K, Sawada S: Effects of lower dose of imatinib to CML patients. Leuk Res 2003;27:1167.

37 Park SJ, Choi IK, Seo HY, Sung HJ, Park KH, Kim SJ, Oh SC, Seo JH, Choi CW, Kim BS, Shin SW, Kim YH, Kim JS: Reduced dose of imatinib for patients with chronic myeloid leukemia and low body surface area. Acta Haematol 2007;118:219-221.

38 Kanda Y, Okamoto S, Tauchi T, Kizaki M, Inokuchi $\mathrm{K}$, Yabe $\mathrm{M}$, Yokoyama $\mathrm{K}$, Ito $\mathrm{Y}$, Kimura Y, Higashihara M, Bessho M, Ando K, Chiba S, Kurokawa M, Oshimi K, Dan K, Ohyashiki K, Ikeda Y: Multicenter prospective trial evaluating the tolerability of imatinib for Japanese patients with chronic myelogenous leukemia in the chronic phase: does body weight matter? Am J Hematol 2008;83:835-839.

39 Sakai M, Miyazaki Y, Matsuo E, Moriuchi Y, Hata T, Fukushima T, Imaizumi Y, Imanishi $D$, Taguchi J, Iwanaga $M$, Tsushima $H$, Inoue Y, Takasaki Y, Tsuchiya T, Komoda M, Ando K, Horio K, Moriwaki Y, Tominaga S, Itonaga $\mathrm{H}$, Nagai K, Tsukasaki K, Tsutsumi C, Sawayama Y, Yamasaki R, Ogawa D, Kawaguchi Y, Ikeda S, Yoshida S, Onimaru Y, Tawara M, Atogami S, Koida S, Joh T, Yamamura M, Matsuo Y, Soda H, Nonaka H, Jinnai I, Kuriyama K, Tomonaga M: Long-term efficacy of imatinib in a practical setting is correlated with imatinib trough concentration that is influenced by body size: a report by the Nagasaki CML study group. Int J Hematol 2009;89:319-325. 
40 Kawaguchi T, Hamada A, Hirayama C, Nakashima R, Nambu T, Yamakawa Y, Watanabe H, Horikawa K, Mitsuya H, Saito H: Relationship between an effective dose of imatinib, body surface area, and trough drug levels in patients with chronic myeloid leukemia. Int J Hematol 2009;89:642-648.

41 Sparano BA, Egorin MJ, Parise RA, Walters J, Komazec KA, Redner RL, Beumer JH: Effect of antacid on imatinib absorption. Cancer Chemother Pharmacol 2009;63:525-528.

42 Egorin MJ, Shah DD, Christner SM, Yerk MA, Komazec KA, Appleman LR, Redner RL, Miller BM, Beumer JH: Effect of a proton pump inhibitor on the pharmacokinetics of imatinib. Br J Clin Pharmacol 2009;68:370374.

43 Bolton AE, Peng B, Hubert M, Krebs-Brown A, Capdeville R, Keller U, Seiberling M: Effect of rifampicin on the pharmacokinetics of imatinib mesylate (Gleevec, STI571) in healthy subjects. Cancer Chemother Pharmacol 2004;53:102-106.

44 Smith P, Bullock JM, Booker BM, Haas CE, Berenson CS, Jusko WJ: The influence of St John's wort on the pharmacokinetics and protein binding of imatinib mesylate. Pharmacotherapy 2004;24:1508-1514.

45 Frye RF, Fitzgerald SM, Lagattuta TF, Hruska MW, Egorin MJ: Effect of St John's wort on imatinib mesylate pharmacokinetics. Clin Pharmacol Ther 2004;76:323-329.

46 Dutreix C, Peng B, Mehring G, Hayes M, Capdeville R, Pokorny R, Seiberling M: Pharmacokinetic interaction between ketoconazole and imatinib mesylate (Glivec) in healthy subjects. Cancer Chemother Pharmacol 2004;54:290-294.

47 Zevin S, Benowitz NL: Drug interactions with tobacco smoking: an update. Clin Pharmacokinet 1999;36:425-438.

48 Van Erp N, Gelderblom H, van Glabbeke M, van Oosterom A, Verweij J, Guchelaar HJ, Debiec-Rychter M, Peng B, Blay JY, Judson I: Effect of cigarette smoking on imatinib in patients in the soft tissue and bone sarcoma group of the EORTC. Clin Cancer Res 2008; 14:8308-8313.

49 Ramanathan RK, Egorin MJ, Takimoto $\mathrm{CH}$, Remick SC, Doroshow JH, Lo Russo PA, Mulkerin DL, Grem JL, Hamilton A, Murgo AJ, Potter DM, Belani CP, Hayes MJ, Peng B, Ivy SP: Phase I and pharmacokinetic study of imatinib mesylate in patients with advanced malignancies and varying degrees of liver dysfunction: a study by the National Cancer Institute organ dysfunction working group. J Clin Oncol 2008;26:563-569.

50 Schmidli H, Peng B, Riviere GJ, Capdeville R, Hensley M, Gathmann I, Bolton AE, Racine-Poon A: Population pharmacokinetics of imatinib mesylate in patients with chronic-phase chronic myeloid leukaemia: results of a phase III study. Br J Clin Pharmacol 2005;60:35-44
51 Pappas P, Karavasilis V, Briasoulis E, Pavlidis N, Marselos M: Pharmacokinetics of imatinib mesylate in end stage renal disease: a case study. Cancer Chemother Pharmacol 2005;56:358-360.

52 Yoo C, Ryu MH, Kang BW, Yoon SK, Ryoo BY, Chang HM, Lee JL, Beck MY, Kim TW Kang YK: Cross-sectional study of imatinib plasma trough levels in patients with advanced gastrointestinal stromal tumors: impact of gastrointestinal resection on exposure to imatinib. J Clin Oncol 2010;28:15541559.

53 White DL, Saunders VA, Dang P, Engler J, Zannettino AC, Cambareri AC, Quinn SR, Manley PW, Hughes TP: OCT-1-mediated influx is a key determinant of the intracellular uptake of imatinib but not nilotinib (AMN107): reduced OCT-1 activity is the cause of low in vitro sensitivity to imatinib. Blood 2006;108:697-704.

54 Wang L, Giannoudis A, Lane S, Williamson P, Pirmohamed M, Clark RE: Expression of the uptake drug transporter HOCT1 is an important clinical determinant of the response to imatinib in chronic myeloid leukemia. Clin Pharmacol Ther 2008;83:258-264.

55 Peng B, Lloyd P, Schran H: Clinical pharmacokinetics of imatinib. Clin Pharmacokinet 2005;44:879-894.

56 De Wildt SN, Kearns GL, Leeder JS, van den Anker JN: Cytochrome p450 3A: ontogeny and drug disposition. Clin Pharmacokinet 1999;37:485-505.

57 Lamba JK, Lin YS, Schuetz EG, Thummel KE: Genetic contribution to variable human CYP3A-mediated metabolism. Adv Drug Deliv Rev 2002;54:1271-1294.

58 Gardner ER, Burger H, van Schaik RH, van Oosterom AT, de Bruijn EA, Guetens G, Prenen H, de Jong FA, Baker SD, Bates SE, Figg WD, Verweij J, Sparreboom A, Nooter $\mathrm{K}$ : Association of enzyme and transporter genotypes with the pharmacokinetics of imatinib. Clin Pharmacol Ther 2006;80: 192-201.

59 Gurney H, Wong M, Balleine RL, Rivory LP, McLachlan AJ, Hoskins JM, Wilcken N, Clarke CL, Mann GJ, Collins M, Delforce SE, Lynch K, Schran H: Imatinib disposition and ABCB1 (MDR1, P-glycoprotein) genotype. Clin Pharmacol Ther 2007;82:33-40.

60 Takahashi N, Miura M, Scott SA, Kagaya H, Kameoka Y, Tagawa H, Saitoh H, Fujishima N, Yoshioka T, Hirokawa M, Sawada K: Influence of CYP3A5 and drug transporter polymorphisms on imatinib trough concentration and clinical response among patients with chronic phase chronic myeloid leukemia. J Hum Genet 2010;55:731-737.

61 Burger $\mathrm{H}$, van Tol H, Brok M, Wiemer EA, de Bruijn EA, Guetens G, de Boeck G, Sparreboom A, Verweij J, Nooter K: Chronic imatinib mesylate exposure leads to reduced intracellular drug accumulation by induction of the ABCG2 (BCRP) and ABCB1 (MDR1) drug transport pumps. Cancer Biol Ther 2005;4:747-752.
62 Burger $\mathrm{H}$, van Tol H, Boersma AW, Brok M, Wiemer EA, Stoter G, Nooter K: Imatinib mesylate (STI571) is a substrate for the breast cancer resistance protein (BCRP)/ABCG2 drug pump. Blood 2004;104:2940-2942.

63 Ozvegy-Laczka C, Hegedus T, Varady G, Ujhelly O, Schuetz JD, Varadi A, Keri G, Orfi L, Nemet K, Sarkadi B: High-affinity interaction of tyrosine kinase inhibitors with the ABCG2 multidrug transporter. Mol Pharmacol 2004;65:1485-1495.

64 Brendel C, Scharenberg C, Dohse M, Robey RW, Bates SE, Shukla S, Ambudkar SV, Wang Y, Wennemuth G, Burchert A, Boudriot U, Neubauer A: Imatinib mesylate and nilotinib (AMN107) exhibit high-affinity interaction with ABCG2 on primitive hematopoietic stem cells. Leukemia 2007;21:12671275.

65 Dohse M, Scharenberg C, Shukla S, Robey RW, Volkmann T, Deeken JF, Brendel C, Ambudkar SV, Neubauer A, Bates SE: Comparison of ATP-binding cassette transporter interactions with the tyrosine kinase inhibitors imatinib, nilotinib, and dasatinib. Drug Metab Dispos 2010;38:1371-1380.

66 Thiebaut F, Tsuruo T, Hamada H, Gottesman MM, Pastan I, Willingham MC: Cellular localization of the multidrug-resistance gene product P-glycoprotein in normal human tissues. Proc Natl Acad Sci USA 1987; 84:7735-7738.

67 Hirano M, Maeda K, Matsushima S, Nozaki Y, Kusuhara H, Sugiyama Y: Involvement of BCRP (ABCG2) in the biliary excretion of pitavastatin. Mol Pharmacol 2005;68:800807.

68 Zhang W, Yu BN, He YJ, Fan L, Li Q, Liu ZQ, Wang A, Liu YL, Tan ZR, Fen J, Huang YF, Zhou HH: Role of BCRP 421C $\rightarrow$ A polymorphism on rosuvastatin pharmacokinetics in healthy Chinese males. Clin Chim Acta 2006;373:99-103.

69 Petain A, Kattygnarath D, Azard J, Chatelut E, Delbaldo C, Geoerger B, Barrois M, Seronie-Vivien S, Le Cesne A, Vassal G: Population pharmacokinetics and pharmacogenetics of imatinib in children and adults. Clin Cancer Res 2008;14:7102-7109.

70 Choi MK, Song IS: Organic cation transporters and their pharmacokinetic and pharmacodynamic consequences. Drug Metab Pharmacokinet 2008;23:243-253.

71 Zhang L, Dresser MJ, Gray AT, Yost SC, Terashita S, Giacomini KM: Cloning and functional expression of a human liver organic cation transporter. Mol Pharmacol 1997;51: 913-921.

72 Zhang L, Schaner ME, Giacomini KM: Functional characterization of an organic cation transporter (hOCT1) in a transiently transfected human cell line (HeLa). J Pharmacol Exp Ther 1998;286:354-361.

73 Zhang L, Brett CM, Giacomini KM: Role of organic cation transporters in drug absorption and elimination. Annu Rev Pharmacol Toxicol 1998;38:431-460. 